\title{
A NON-DESTRUCTIVE METHOD FOR ESTIMATING LEAF AREA OF Ceiba glaziovii (Kuntze) K. Schum.
}

\author{
João Everthon da Silva Ribeiro ${ }^{1}$, Francisco Romário Andrade Figueiredo ${ }^{2}$, Ester dos Santos Coêlho ${ }^{3}$, Walter \\ Esfrain Pereira ${ }^{1}$, Manoel Bandeira de Albuquerque ${ }^{1}$
${ }^{1}$ Universidade Federal da Paraíba, Programa de Pós-Graduação em Agronomia, Areia, Paraíba, Brasil - j.everthon@ @otmail.com*, walterufpb@yahoo.com.br, manoel1977@gmail.com
${ }^{2}$ Universidade Federal Rural do Semi-Árido, Programa de Pós-Graduação em Fitotecnia, Mossoró, Rio Grande do Norte, Brasil - romarioagroecologia@yahoo.com.br \\ ${ }^{3}$ Universidade Federal da Paraíba, Graduação em Agronomia, Areia, Paraíba, Brasil - estersantos12@hotmail.com
}

Received for publication: 19/08/2018 - Accepted for publication: 29/05/2019

\begin{abstract}
Resumo
Método não destrutivo para estimativa da área foliar de Ceiba glaziovii (Kuntze) K. Schum. A determinação da área foliar é de fundamental importância em estudos que envolvem aspectos ecológicos e ecofisiológicos de espécies florestais. Objetivou-se nesta pesquisa ajustar uma equação que permita determinar a área foliar de Ceiba glaziovii em função de medidas lineares das folhas. Coletaram-se 600 limbos foliares saudáveis em diferentes matrizes, com formas e tamanhos variados, no Parque Estadual Mata do Pau-Ferro, município de Areia, estado da Paraíba, Nordeste do Brasil. Calculou-se o comprimento máximo (L), largura máxima (W), produto entre comprimento e largura (L.W), e a área folia real dos limbos foliares. Os modelos de regressão utilizados para construção de equações foram: linear, linear sem intercepto, quadrático, cúbico, potência e exponencial. Os critérios para escolha da melhor equação foram baseados no coeficiente de determinação $\left(\mathrm{R}^{2}\right)$, critério de informação de Akaike (AIC), raiz do erro médio quadrático (RMSE), índice de concordância de Willmott $(d)$ e índice BIAS. Todas as equações propostas estimam satisfatoriamente a área foliar de C. glaziovii, pelo fato de apresentarem coeficientes de determinação elevados $\left(\mathrm{R}^{2} \geq 0,851\right)$. O modelo linear sem intercepto, utilizando o produto entre comprimento e largura (L.W), apresentou os melhores critérios para estimar a área foliar da espécie, utilizando-se a equação $0,4549 * \mathrm{LW}$.

Palavras-chave: Barriguda, medidas lineares, biometria, Malvaceae.
\end{abstract}

\begin{abstract}
The determination of leaf area is of fundamental importance in studies involving ecological and ecophysiological aspects of forest species. The objective of this research was to adjust an equation to determine the leaf area of Ceiba glaziovii as a function of linear measurements of leaves. Six hundred healthy leaf limbs were collected in different matrices, with different shapes and sizes, in the Mata do Pau-Ferro State Park, Areia, Paraíba state, Northeast Brazil. The maximum length (L), maximum width (W), product between length and width (L.W), and leaf area of the leaf limbs were calculated. The regression models used to construct equations were: linear, linear without intercept, quadratic, cubic, power and exponential. The criteria for choosing the best equation were based on the coefficient of determination $\left(\mathrm{R}^{2}\right)$, Akaike information criterion (AIC), root mean square error (RMSE), Willmott concordance index (d) and BIAS index. All the proposed equations satisfactorily estimate the leaf area of $C$. glaziovii, due to their high determination coefficients $\left(\mathrm{R}^{2} \geq 0.851\right)$. The linear model without intercept, using the product between length and width (L.W), presented the best criteria to estimate the leaf area of the species, using the equation $0.4549 * \mathrm{LW}$.

Key words: Barriguda, linear meansurements, biometry, Malvaceae.
\end{abstract}

\section{INTRODUCTION}

Ceiba glaziovii (Kuntze) K. Schum. is a tree species popularly known in Brazil as "barriguda" (potbellied) or "paineira-branca" (white-paineira), belonging to the family Malvaceae. Its distribution and ecological range are restricted to Northeast Brazil, with records for the states of Ceará, Bahia, Pernambuco and Paraíba (NASCIMENTO, 2012). It occurs in Caatinga vegetation and areas of mountainous relief, as well as in rainforests of the Atlantic Forest surrounded by xerophilous vegetation known as "Brejos de Altitude" (LEAL et al., 2011). The stem bark of barriguda is used in traditional medicine to treat various diseases, such as inflammation, hypertension, diabetes and rheumatism, among others (SILVA et al., 2015). The fruits are of high economic importance, mainly serving as food for fauna, which consume the seeds and rind even when immature (GUEDES; ALVES, 2011). The seeds are also used in the manufacture of upholstery such as pillows and mattresses (SILVA et al., 2016).

FLORESTA, Curitiba, PR, v. 50, n. 1, p. 1063 - 1070, jan/mar 2020.

Ribeiro, J. E. S. et.al.

ISSN eletrônico 1982-4688 
Due to the economic and environmental importance of the species in different regions, ecophysiological studies involving aspects related to plant growth, propagation and reproduction are necessary. The determination of leaf area is paramount for such studies since it is the most important parameter in studies involving plant growth and development (TAIZ et al., 2017). Leaf area is of fundamental importance to ecophysiology of plants because it relates to photosynthetic efficiency of plants, regulation of biotic and abiotic damage, analysis of dry matter production and plant metabolism (TAIZ et al., 2017).

Leaf area can be determined by different methods and are classified as direct or indirect and destructive or non-destructive (MALAGI et al., 2010). Destructive methods are considered simple and accurate but use highcost equipment and take longer for analysis, as well as causing total damage to the plant (MOTA et al., 2014). In contrast, non-destructive methods allow accurate and quick multiple evaluations of the same plant without destroying the leaves, thus enabling plant growth to be monitored over space and time.

The use of regression models has become a very precise non-destructive method that allows the real leaf area of plants to be estimated from linear measurements of leaf blades (length and width), which are directly correlated with leaf surface area (ZHANG; PAN, 2011). Such methods have been used to estimate leaf area of both cultivated (GANESHAMURTHY et al., 2016; CARVALHO et al., 2017; OLIVEIRA et al., 2017) and forest species (ASSIS et al., 2015; KERAMATLOU et al., 2015; RIBEIRO et al., 2018b; RIBEIRO et al., 2019a; RIBEIRO et al., 2019b).

There is very little information in the literature abut estimating leaf area of forest species, making it difficult to understand the growth, ecology and conservation of these species in various regions of their occurrence. Thus, the objective of the present research was to construct a statistical model for determining the real leaf area of Ceiba glaziovii from linear dimensions of leaf blades.

\section{MATERIAL AND METHODS}

The research was conducted in Parque Estadual Mata do Pau-Ferro, located in the city of Areia, state of Paraíba, Northeast Brazil (6 58'12" S and 35 42’15” W) (Figure 1). The region has an annual average temperature of $22^{\circ} \mathrm{C}$ (RIBEIRO et al., 2018a), with elevation ranging from 400 to 600 meters and a tropical climate, classified as Aw according to Peel et al. (2007).
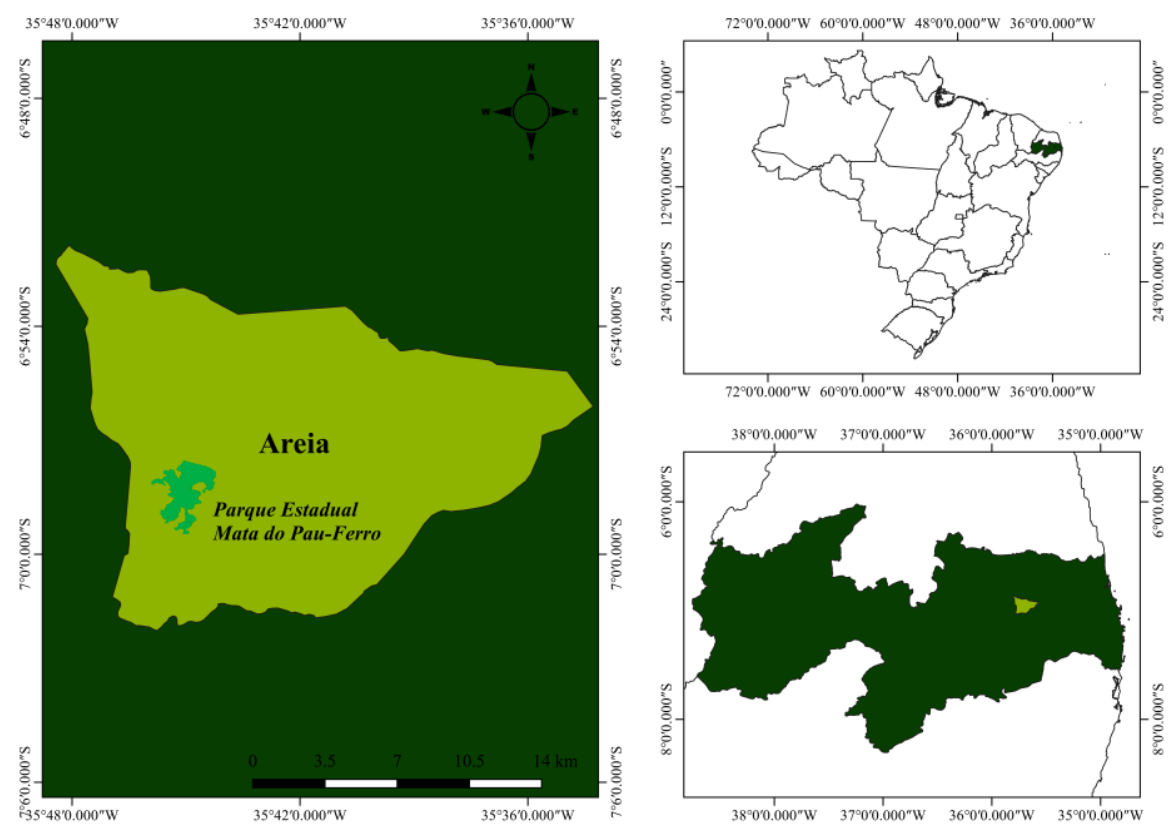

Figura 1. Localização geográfica do Parque Estadual Mata do Pau-Ferro, município de Areia, estado da Paraíba, Brasil.

Figure 1. Geographic location of Mata do Pau-Ferro State Park, Areia, Paraíba state, Brazil.

A total of 600 leaf blades of different sizes and without damage from pests, diseases or climate factors, were collected from matrices of $C$. glaziovii. The leaf blades were stored in plastic bags and packed in containers with ice to prevent water loss. The leaf blades were subsequently sent to Laboratório de Ecologia Vegetal of 
Universidade Federal da Paraíba (Campus II) to measure the maximum length (L) and width (W) (Figure 2) of each using a millimeter ruler. The product of the length and width (L.W) of each leaf was subsequently calculated. The leaf blades were then digitized by a flatbed scanner (Canon model P-215II), and the images processed with the public domain software ImageJ® to determine real leaf area (LA) (RIBEIRO et al., 2018b).

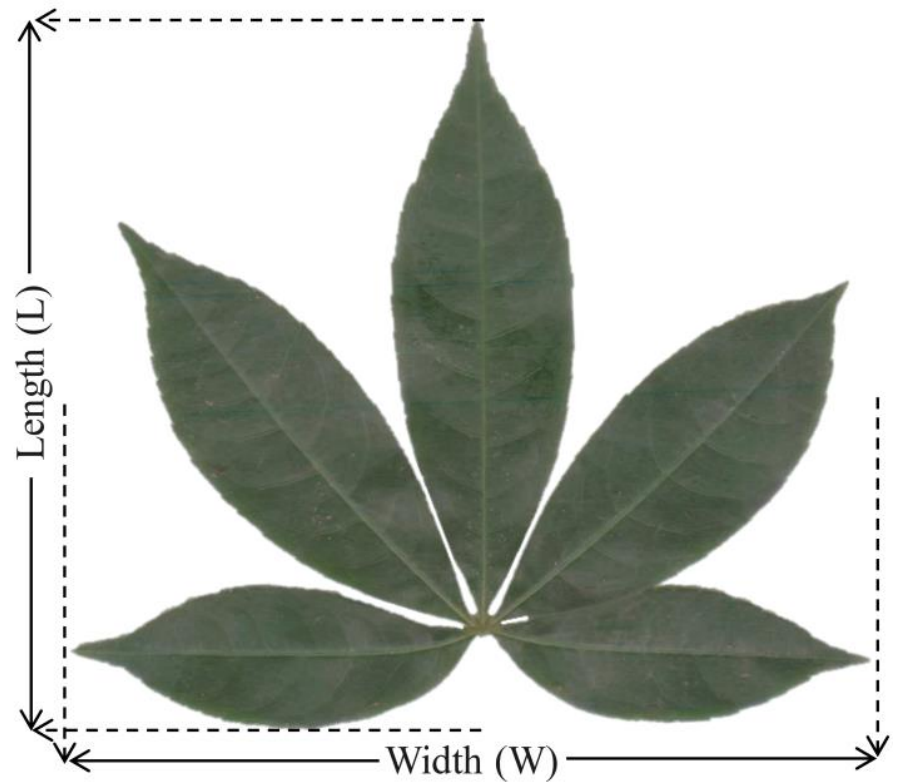

Figura 2. Medições do comprimento máximo (L) e largura máxima (W) do limbo foliar de Ceiba glaziovii utilizado para estimativa da área foliar.

Figure 2. Measurements of maximum length (L) and maximum width (W) of leaf limb of Ceiba glaziovii used for leaf area estimation.

Data of length (L), width (W), the product of length $\mathrm{x}$ width (L.W), and real leaf area (LA) of the 600 leaf blades were used to calculate the minimum, maximum and average values; the median, standard error, standard deviation, coefficient of variation, asymmetry, kurtosis and normality were evaluated by the Lilliefors test.

Simple linear $(\hat{y}=a+b x)$, intercept-free linear $(\hat{y}=b x)$, quadratic $\left(\hat{y}=a+b x+c x^{2}\right)$, cubic $(\hat{y}=$ $\left.a+b x+c x^{2}+d x^{3}\right)$, potential $\left(\hat{y}=a x^{b}\right)$, and exponential $\left(\hat{y}=a b^{x}\right)$ regression models were used to choose the best equation for estimating leaf area of $C$. glaziovii from leaf blade dimensions (L, W and / or L.W). The dependent variable ' $\hat{y}$ ' estimated real leaf area (LA) as a function of the independent variable ' $x$ ', whose values were determined from length (L), width (W) or their product (L.W). The following criteria were used to choose the best model to determine leaf area for $C$. glaziovii from linear leaf blade dimensions: coefficient of determination $\left(\mathrm{R}^{2}\right)$ and Willmott's concordance index $(d)$ closest to one (WILLMOTT et al., 1985); lower Akaike information criterion (AIC) and root mean square error (RMSE); and BIAS index closest to zero. Statistical analyses were performed using R® software v.3.5.1., using the package hydroGOF.

\section{RESULTS}

The leaf blades of $C$. glaziovii varied in length (L) from 1.57 to $13.94 \mathrm{~cm}$, with a mean of $8.59 \mathrm{~cm}$; width (W) varied from 0.90 to $17.96 \mathrm{~cm}$ with a mean of $10.85 \mathrm{~cm}$; and real leaf area (LA) varied from 0.49 to 109.87 $\mathrm{cm}^{2}$ with a mean of $45.80 \mathrm{~cm}^{2}$.

Length and width had the lowest coefficients of variation (25.88 and $31.58 \%$, respectively), while the product of length $\mathrm{x}$ width $(50.72 \%)$ and real leaf area $(51.56 \%)$ had the highest (Table 1$)$.

According to the kurtosis coefficient $(k)$, all variables analyzed exhibited a platykurtic distribution $(k<$ 3) (Table 1). All data evaluated did not fit a normal distribution according to Lilliefors test $(\mathrm{p}<0.05)($ Table 1$)$. The deviations found in asymmetry and kurtosis coefficients were essential for the deviation from normality in all variables (L, W, L.W and LA) (Table 1).

The dispersion diagram of the relationships between length $(\mathrm{L})$, width $(\mathrm{W})$, their product $(\mathrm{L} . \mathrm{W})$ and real leaf area (LA) revealed different patterns of association of the data by linear and non-linear models (Figure 3).

FLORESTA, Curitiba, PR, v. 50, n. 1, p. 1063 - 1070, jan/mar 2020.

Ribeiro, J. E. S. et.al.

ISSN eletrônico 1982-4688 
Tabela 1. Valor mínimo, máximo, médio, mediana, erro padrão, desvio-padrão, coeficiente de variação, assimetria, curtose e teste de Lilliefors para comprimento $(\mathrm{L})$, largura $(\mathrm{W})$, produto entre comprimento e largura (L.W), e área foliar real (LA) de 600 limbos foliares de Ceiba glaziovii.

Table 1. Minimum, maximum, mean, median, standard error, standard deviation, coefficient of variation, asymmetry, kurtosis and Lilliefors test for length (L), width (W), product between length and width (L.W), and real leaf area (LA) of 600 leaf limbs of Ceiba glaziovii.

\begin{tabular}{|c|c|c|c|c|}
\hline Descriptive Statistic & $\mathbf{L}(\mathbf{c m})$ & $\mathbf{W}(\mathbf{c m})$ & L.W $\left(\mathrm{cm}^{2}\right)$ & $\mathbf{L A}\left(\mathbf{c m}^{2}\right)$ \\
\hline Minimum & 1.575 & 0.905 & 1.8553 & 0.493 \\
\hline Maximum & 13.94 & 17.963 & 247.895 & 109.871 \\
\hline Mean & 8.595 & 10.854 & 100.362 & 45.803 \\
\hline Median & 8.600 & 11.058 & 95.051 & 45.219 \\
\hline Standard error & 0.090 & 0.139 & 2.078 & 0.9642 \\
\hline Standard deviation & 2.224 & 3.427 & 50.900 & 23.617 \\
\hline C.V. $(\%)$ & $25.88 \%$ & $31.58 \%$ & $50.72 \%$ & $51.56 \%$ \\
\hline Asymmetry ${ }^{a}$ & -0.367 & -0.358 & 0.350 & 0.193 \\
\hline Kurtosis $+3^{\mathrm{b}}$ & 2.968 & 2.930 & 2.539 & 2.246 \\
\hline Lilliefors & $0.041 *$ & $0.008 * *$ & $<0.001 * *$ & $<0.001 * *$ \\
\hline
\end{tabular}

${ }^{a}$ Asymmetry differs from zero by t-test at $5 \%$ probability;

${ }^{\mathrm{b}}$ Kurtosis differs from three by the t-test at $5 \%$ probability;

* Significant at $5 \%$ probability;

** Significant at $1 \%$ probability.
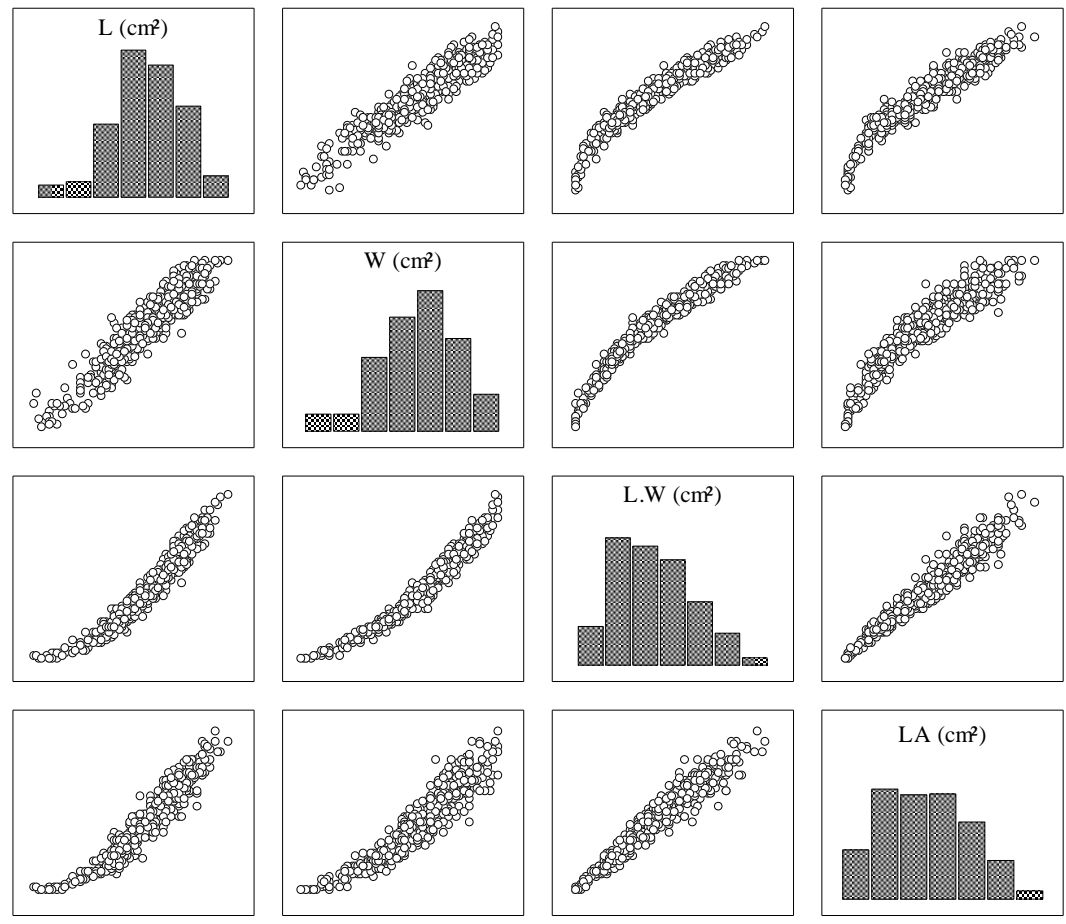

Figura 3. Histograma (na diagonal) e gráficos de dispersão entre o comprimento (L), largura (W), produto entre comprimento e largura (L.W), e área foliar real (LA) de 600 limbos foliares de Ceiba glaziovii.

Figure 3. Histogram (diagonal) and scatter plots between length (L), width (W), product between length and width (L.W), and real leaf area (LA) of 600 leaf limbs of Ceiba glaziovii.

Table 2 shows the percentage distribution for the 600 leaf blades of $C$. glaziovii in relation to the different size ranges. It was found that $41.2 \%$ of the measured leaf areas were associated with leaves ranging from 15.01 to $45.0 \mathrm{~cm}^{2}$, demonstrating that most of the leaves of this forest species are of medium size. 
Tabela 2. Distribuição (\%) de 600 limbos foliares de Ceiba glaziovii em relação a diferentes faixas de tamanho. Table 2. Distribution (\%) of 600 leaf limbs of Ceiba glaziovii in relation to different size ranges.

\begin{tabular}{cc}
\hline $\mathbf{L A}\left(\mathbf{c m}^{2}\right)$ & $\mathbf{( \% )}$ \\
\hline$[0.45-15.0]$ & 8.7 \\
{$[15.01-30.0]$} & 22.2 \\
{$[30.01-45.0]$} & 19.0 \\
{$[45.01-60.0]$} & 21.0 \\
{$[60.01-75.0]$} & 16.5 \\
{$[75.01-90.0]$} & 9.8 \\
{$[90.01-110.0]$} & 2.8 \\
\hline
\end{tabular}

The models constructed from regression analysis relating real leaf area $(\hat{y})$ as a function of leaf blade length (L), width (W) and their product (L.W) are presented in Table 4. The values for the determination coefficients were considered high $\left(\mathrm{R}^{2} \geq 0.851\right)$ (Table 3$)$, allowing any of the proposed equations to be used to satisfactory estimate the leaf area of $C$. glaziovii. According to the criteria used, and greater practicality for calculation, the intercept-free linear model (straight line goes through the origin) using the product between length and width (L.W) presented the highest values for $\mathrm{R}^{2}$ and $d(0.9866$ and 0.9850 , respectively), lowest values for AIC (3792.0) and RMSE (5.656), and a BIAS index closest to zero (0.050) (Table 3). Thus, leaf area of de $C$. glaziovii can be measured using this equation $\hat{y}=0.4549^{*} \mathrm{LW}$, which corresponds to $45.49 \%$ of the product of length and width (L.W).

Figure 4 shows that there was little dispersion of the data in relation to the straight line obtained by curve fitting. Based on this, leaf area estimated through the indicated model $\left(\hat{y}=0.4549^{*} \mathrm{LW}\right)$ presented a satisfactory relationship with real leaf area since the Pearson correlation coefficient (r) between these two parameters was 0.9677 (Figure 5).

Tabela 3. Modelos, equações propostas, coeficiente de determinação ( $\left.\mathrm{R}^{2}\right)$, critério de informação de Akaike (AIC), raiz do erro médio quadrático (RMSE), índice de concordância de Willmott $(d)$ e índice BIAS em função de medidas lineares dos limbos foliares de Ceiba glaziovii.

Table 3. Models, proposed equations, coefficient of determination $\left(\mathrm{R}^{2}\right)$, Akaike information criterion (AIC), root mean square error (RMSE), Willmott concordance index $(d)$ and BIAS index as a function of linear measurements of leaf limbs of Ceiba glaziovii.

\begin{tabular}{|c|c|c|c|c|c|c|c|}
\hline Model & $\mathbf{x}^{(1)}$ & Proposed equation & $\mathbf{R}^{2}$ & AIC & RMSE & $d$ & BIAS \\
\hline Linear & $\mathrm{L}$ & $\hat{y}=-40.90+10.09 * \mathrm{~L}$ & 0.9023 & 4105.3 & 7.368 & 0.9737 & 0.169 \\
\hline Linear & W & $\hat{y}=-24.082+6.438 * W$ & 0.8728 & 4264.0 & 8.410 & 0.9650 & 0.150 \\
\hline Linear & LW & $\hat{y}=0.738+0.449 * L W$ & 0.9364 & 3847.8 & 5.945 & 0.9833 & 0.085 \\
\hline Linear $(0.0)$ & LW & $\hat{y}=0.4549 * L W$ & 0.9866 & 3792.0 & 5.656 & 0.9850 & 0.050 \\
\hline Quadratic & $\mathrm{L}$ & $\hat{\mathrm{y}}=-10.212+1.972 * \mathrm{~L}+0.495 * \mathrm{~L}^{2}$ & 0.9240 & 3955.8 & 6.494 & 0.9799 & 0.059 \\
\hline Quadratic & W & $\hat{\mathrm{y}}=-8.254+2.945 * \mathrm{~W}+0.170 * \mathrm{~W}^{2}$ & 0.8855 & 4201.9 & 7.972 & 0.9689 & 0.053 \\
\hline Quadratic & LW & $\hat{y}=-4.290+0.567 * L W-0.0005 * L^{2}$ & 0.9413 & 3847.6 & 5.893 & 0.9847 & 0.052 \\
\hline Cubic & $\mathrm{L}$ & $\hat{y}=15.113-10.397 * \mathrm{~L}+2.254 * \mathrm{~L}^{2}-0.076 * \mathrm{~L}^{3}$ & 0.9291 & 3915.2 & 6.267 & 0.9814 & 0.148 \\
\hline Cubic & W & $\hat{y}=8.005-3.905 * \mathrm{~W}+0.958 * \mathrm{~W}^{2}-0.026 * \mathrm{~W}^{3}$ & 0.8921 & 4167.1 & 7.732 & 0.9709 & -0.131 \\
\hline Cubic & LW & $\hat{y}=-1.546+0.450 * \mathrm{LW}+0.0006 * \mathrm{LW}^{2}-0.000003 * \mathrm{LW}^{3}$ & 0.9834 & 3800.6 & 5.706 & 0.9835 & 0.051 \\
\hline Potential & $\mathrm{L}$ & $\hat{y}=0.517 * L^{2.054}$ & 0.9222 & 3974.5 & 6.607 & 0.9787 & -0.242 \\
\hline Potential & W & $\hat{\mathrm{y}}=0.840 * \mathrm{~W}^{1.655}$ & 0.8862 & 4199.7 & 7.971 & 0.9684 & -0.168 \\
\hline Potential & LW & $\hat{y}=0.563 * L^{0.956}$ & 0.9423 & 3837.3 & 5.954 & 0.9379 & -0.191 \\
\hline Exponential & $\mathrm{L}$ & $\hat{y}=6.624 * 1.238^{\mathrm{L}}$ & 0.8934 & 4175.1 & 7.809 & 0.9687 & -0.527 \\
\hline Exponential & W & $\hat{y}=9.626^{*} 1.145^{\mathrm{w}}$ & 0.8512 & 4372.1 & 9.202 & 0.9549 & -0.546 \\
\hline Exponential & LW & $\hat{y}=19.455^{*} 1.008^{\mathrm{LW}}$ & 0.8512 & 4384.8 & 9.202 & 0.9549 & -0.546 \\
\hline
\end{tabular}

(1) Linear measurements: length (L) and width (W).

FLORESTA, Curitiba, PR, v. 50, n. 1, p. 1063 - 1070, jan/mar 2020. 


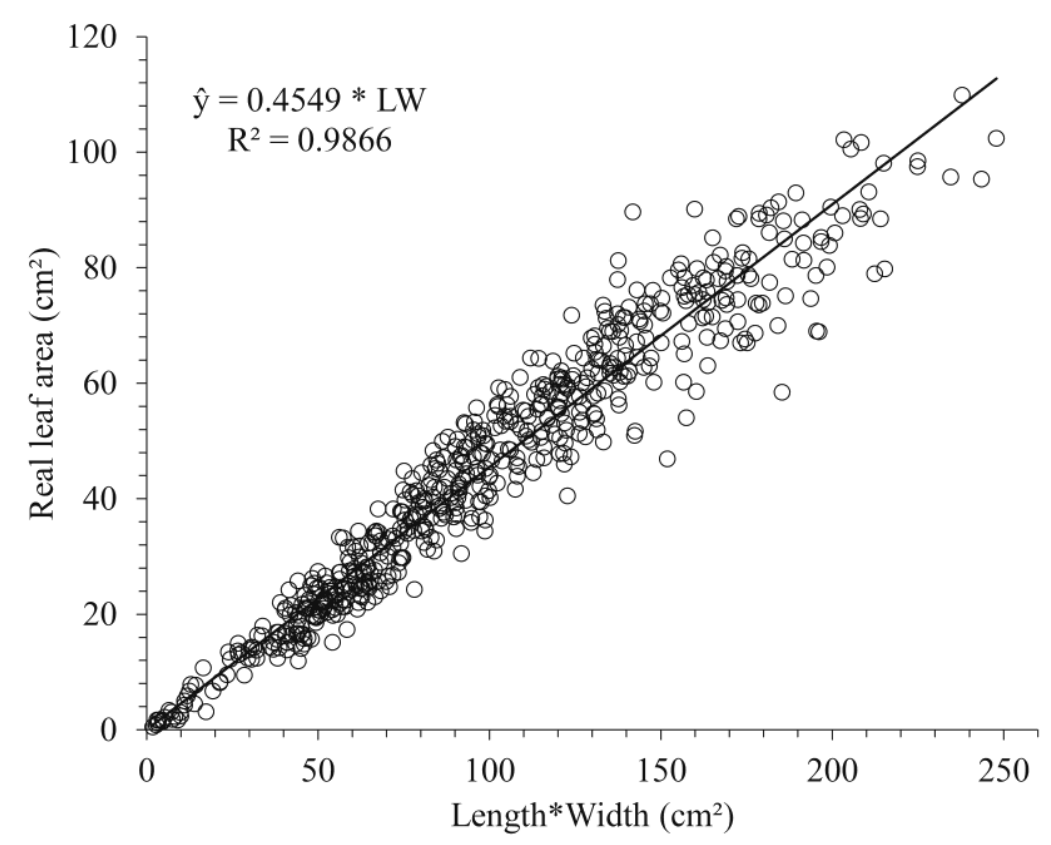

Figura 4. Relação entre a área foliar real (LA) de Ceiba glaziovii em função do produto entre comprimento e largura (L.W) dos limbos foliares, através da equação indicada para mensuração da área foliar.

Figure 4. Relationship between the real leaf area (LA) of Ceiba glaziovii as a function of the product between length and width (L.W) of the leaf limbs, through the equation indicated for measuring the leaf area.

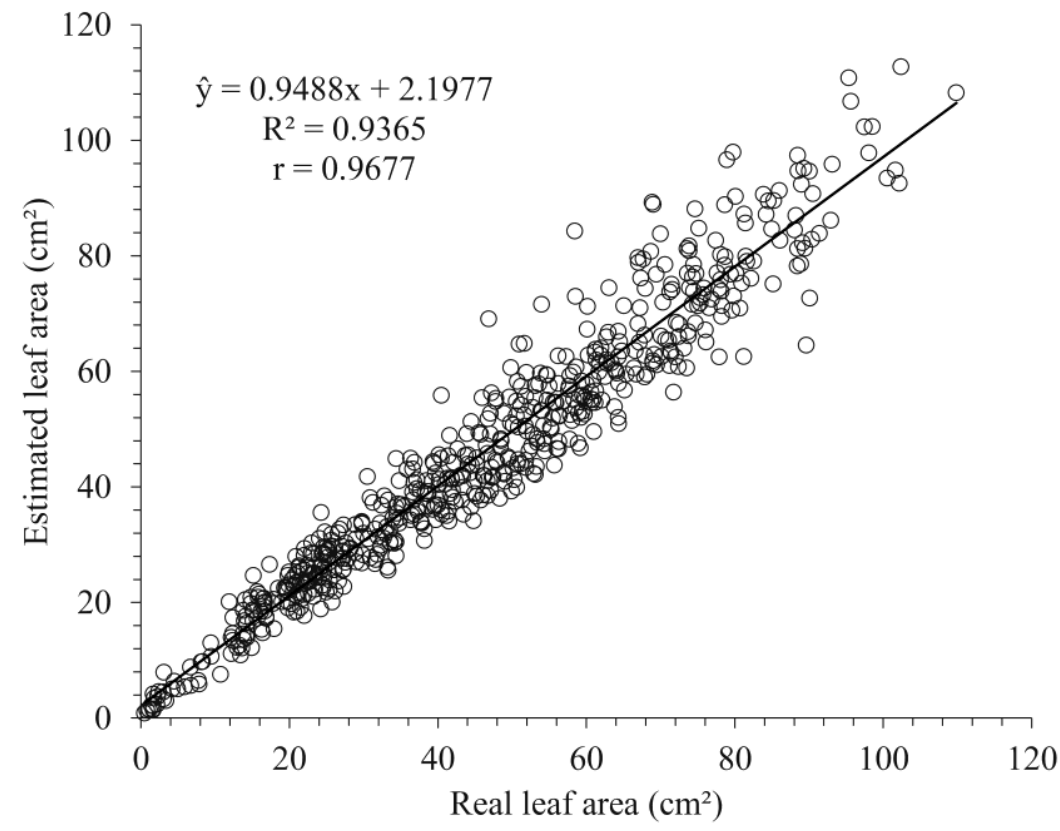

Figura 5. Relação entre a área foliar real e área foliar estimada pela equação $\hat{y}=0,4549 * \mathrm{LW}$.

Figure 5. Relation between the real leaf area and estimated leaf area by equation $\hat{y}=0.4549 * \mathrm{LW}$.

\section{DISCUSSION}

Values for length and width showed less variability compared to their product and real leaf area. This high variability for the product and leaf area was of fundamental importance for generating regression models to determine the leaf area for $C$. glaziovii from linear leaf blade dimensions, which in turn allows multiple evaluations 
of leaves of different shapes and sizes (CARGNELUTTI FILHO et al., 2012). Thus, the amount of leaf blades collected (600 leaf blades) was adequate to estimate leaf area for the species as a function of leaf dimensions.

Regarding normality of the data, all variables analyzed presented a platykurtic distribution, which indicates that the frequency distribution function of the evaluated variables is flatter than the normal distribution. Similar results for data distribution were found by Toebe et al. (2012) in a study on leaf area estimation of leaf blades of Phaseolus vulgaris L..

The dispersion diagram relating the evaluated parameters showed both linear and non-linear associations, which has been previously demonstrated by other researchers in similar studies (TOEBE et al., 2012b; CARGNELUTTI FILHO et al., 2015; CARVALHO et al., 2017).

Regarding the leaf dimensions, the models that used the product of length $\mathrm{x}$ width $(\mathrm{LxW})$ were more suitable for estimating leaf area of $C$. glaziovii than those that used just length (L) or width (W). This finding is in agreement with Mota et al. (2014) and Assis et al. (2015), who constructed precise equations from the product of length x width (L.W) of leaf blades for Acrocomia aculeata and Merremia Merremia aegyptia, respectively.

The intercept-free linear model, obtained through the product of the measurements of length and width (L.W), is the most suitable for estimating leaf area of $C$. glaziovii. This model was also recommended for determining leaf area of other species such as those of Combretum leprosum Mart. (CANDIDO et al., 2013), Hymenaea courbaril L. (SANTOS et al., 2016), Crotalaria juncea L. (CARVALHO et al., 2017) and Erythroxylum simonis Plowman (RIBEIRO et al., 2018b).

\section{CONCLUSIONS}

- Estimation of leaf area of C. glaziovii can be determined using a non-destructive method.

- The intercept-free linear model $\hat{y}=0.4549 * \mathrm{LW}$, using the product of measurements of length and width, can satisfactorily estimate leaf area of C. glaziovii.

- This model for estimating leaf area of C. glaziovii is of fundamental importance for future species-related studies that contribute to its preservation and conservation in forest remnants of Caatinga and Atlantic Forest.

\section{REFERENCES}

ASSIS, J. P. de; LINHARES, P. C. F.; SOUZA, R. P. de; PEREIRA, M. F. S.; ALMEIDA, A. M. B. de. Estimação da área foliar da "jitirana" (Merremia aegyptia (L.) Urban), através de modelos de regressão para Mossoró - RN. Revista Verde de Agroecologia e Desenvolvimento Sustentável, Pombal, v. 10, n. 4, p. 75 - 81, 2015.

CANDIDO, W. S.; COELHO, M. de F. B.; MAIA, S. S. S.; CUNHA, C. S. de M. C.; SILVA, R. C. P. de. Modelo para estimar a área foliar de Combretum leprosum Mart. Acta Agronômica, Bogotá, v. 62, n. 1, p. 37 - 41, 2013.

CARGNELUTTI FILHO, A.; TOEBE, M.; BURIN, C.; FICK, A. L.; CASAROTTO, G. Estimativa da área foliar de nabo forrageiro em função de dimensões foliares. Bragantia, Campinas, v. 71, n. 1, p. 47 - 51, 2012.

CARGNELUTTI FILHO, A.; TOEBE, M.; ALVES, B. M.; BURIN, C.; KLEINPAUL, J. A. Estimação da área foliar de canola por dimensões foliares. Bragantia, Campinas, v. 74, n. 2, p. 139 - 148, 2015.

CARVAlHO, J. O. de; TOEBE, M.; TARTAGLIA, F. L.; BANDEIRA, C. T.; TAMBARA, A. L. Leaf area estimation from linear measurements in different ages of Crotalaria juncea plants. Anais da Academia Brasileira de Ciências, Rio de Janeiro, v. 89, n. 3, p. 1851 - 1868, 2017.

GANESHAMURTHY, A. N.; RAVINDRA, V.; VENUGOPALAN, R.; MATHIAZHAGAN, M.; BHAT, R. M. Biomass distribution and development of a allometric equations for non-destructive estimation of carbon sequestration in Grafted Mango Trees. Journal of Agricultural Science, Toronto, v. 8, n. 8, p. 201 - 211 , 2016.

GUEDES, R. S.; ALVES, E. U. Substrates and temperatures for the germination test of Chorisia glaziovii (O. Kuntze) seeds. Cerne, Lavras, v. 17, n. 4, p. 525 - 531, 2011.

KERAMATLOU, I.; SHARIFANI, M.; SABOURI, H.; ALIZADEHA, M.; KAMKAR, B. A simple linear model for leaf area estimation in Persian walnut (Juglans regia L.). Scientia Horticulturae, Cape Town, v. 184, n. 1, p. $36-39,2015$.

LEAL, A. J. de B.; DANTAS, I. C.; CHAVES, T. P.; FELISMiNO, D. de C.; VIEIRA, K. V. M. Estudo fitoquímico antimicrobiano de Ceiba Glaziovii Kuntze K. Schum. Revista de Biologia e Farmácia, Campina Grande, v. 5, n. 1, p. 73 - 77, 2011.

FLORESTA, Curitiba, PR, v. 50, n. 1, p. 1063 - 1070, jan/mar 2020.

Ribeiro, J. E. S. et.al.

ISSN eletrônico 1982-4688

1069

DOI: $10.5380 /$ rf.v50 i1.61088 
MALAGI, G.; CITADIN, I.; SCARIOT, S.; REIS, L. Non-destructive method for leaf area determination of grapevine 'brs-violeta' cultivar. Revista Brasileira de Fruticultura, Jaboticabal, v. 32, n. 4, p. 1250 - 1254, 2010.

MOTA, C. S.; LEITE, H. G.; CANO, M. A. O. Equações para estimar área foliar de folíolos de Acrocomia aculeta. Pesquisa Florestal Brasileira, Colombo, v. 34, n. 79, p. 217 - 224, 2014.

NASCIMENTO, I. L. Superação da dormência em sementes de paineira-branca. Cerne, Lavras v. 18, n. 2, p. 285 - 291, 2012.

OLIVEIRA, O. S.; SILVA, W.; COSTA, A. A. M.; SCHMILDT, E. R.; VITÓRIA, E. L. da. Leaf area estimation in litchi by means of allometric relationships. Revista Brasileira de Fruticultura, Jaboticabal, v. 39, n. Spe, p. 1 $-6,2017$.

PEEL, M. C.; FINLAYSON, B. L.; MCMAHON, T. A. Updated world map of the Köppen-Geiger climate classification. Hydrology and Earth System Sciences, Canberra, v. 11, p. 1633 - 1644, 2007.

RIBEIRO, J. E. da S.; BARBOSA, A. J. S.; LOPES, S. de F.; PEREIRA, W. P.; ALBUQUERQUE, M. B. de. Seasonal variation in gas exchange by plants of Erythroxylum simonis Plowman. Acta Botanica Brasílica, Belo Horizonte, v. 32, n. 2, p. 287 - 296, 2018a.

RIBEIRO, J. E. da S.; BARBOSA, A. J. S.; ALBUQUERQUE, M. B. de. Leaf area estimate of Erythroxylum simonis Plowman by linear dimensions. Floresta e Ambiente, Seropédica, v. 25, n. 2, p. 1 - 7, 2018 b.

RIBEIRO, J. E. da S.; COÊLHO, E. dos. S.; FIGUEIREDO, F. R. A.; PEREIRA, W. E.; ALBUQUERQUE, M. B. de. Leaf area estimation for Psychotria carthagenensis and Psychotria hoffmannseggiana as a function of linear leaf dimensions. Acta Scientiarum. Biological Sciences, Maringá, v. 41, p. 1 - 8, 2019 a.

RIBEIRO, J. E. da S.; COÊLHO, E. dos. S.; FIGUEIREDO, F. R. A.; LOPES, S. de F.; ALBUQUERQUE, M. B. de. Estimation of leaf area of Erythroxylum citrifolium from linear leaf dimensions. Bioscience Journal, Uberlândia, v. 35, n. 6, p. 1923 - 1931, 2019 b.

SANTOS, J. C. C. dos; COSTA, R. N.; SIlVA, D. M. R.; SOUZA, A. A. de; MOURA, F. de B. P.; SILVA JUNIOR, J. M. da; SILVA, J. V. Use of allometric models to estimate leaf area in Hymenaea courbaril L. Theoretical and Experimental Plant Physiology, London, v. 28, n. 4, p. 357 - 369, 2016.

SILVA, C. G.; MARINHO, M. G. V.; LUCENA, M. F. A.; COSTA, J. G. M. Ethnobotanical survey of medicinal plants in the Caatinga area in the community of Sitio Nazaré, Milagres, Ceará, Brazil. Revista Brasileira de Plantas Medicinais, Botucatu, v. 17, n. 1, p. 136 - 142, 2015.

SILVA, M. L. M. da; ALVES, E. U.; BRUNO, R. de L. A.; SANTOS-MOURA, S. da S.; SANTOS NETO, A. P. Germinação de sementes de Chorisia glaziovii O. Kuntze submetidas ao estresse hídrico em diferentes temperaturas. Ciência Florestal, Santa Maria, v. 26, n. 3, p. 999 - 1007, 2016.

TAIZ, L.; ZEIGER, E.; MOLLER, I.; MURPHY, A. Fisiologia e desenvolvimento vegetal. Porto Alegre: Artmed, 6 ed. 2017,888 p.

TOEBE, M.; CARGNELUTTI FILHO, A.; LOOSE, L. A.; HELDWEIN, A. B.; ZANON, A. J. Leaf area of snap bean (Phaseolus vulgaris L.) according to leaf dimensions. Semina, Londrina, v. 33, n. 6, p. 2491 - 2500, $2012 \mathrm{a}$.

TOEBE, M.; CARGNELUTTI FILHO, A.; BURIN, C.; FICK, A. L.; NEU, I. M. M.; CASAROTTO, G.; ALVES, B. M. Leaf area prediction models for jack bean by leaf dimensions. Bragantia, Campinas, v. 71, n. 1, p. 37 - 41, 2012b.

WILlMOTT, C. J.; ACKLESON, S. G.; DAVIS, R. E.; FEDDEMA, J. J.; KLINK, K. M.; LEGATES, D. R.; O'DONNELL, J.; ROEW, C. M. Statistics for the evaluation and comparison of models. Journal of Geophysical Research, London, v. 90, n. C5, p. 8995 - 9005, 1985.

ZHANG, L.; PAN, L. Allometric models for leaf area estimation across different leaf-age groups of evergreen broadleaved trees in a subtropical forest. Photosynthetica, London, v. 49, n. 2, p. 219 - 226, 2011. 